\title{
Correlation of Minimum Miscibility Pressure for Hydrocarbon Gas Injection In Southern Iraqi Oil Fields
}

\author{
Liqaa I.Hadi', Sameera M. Hamd-Allah ${ }^{2, *}$ \\ ${ }^{1}$ Department of Petroleum Engineering, University of Baghdad, Baghdad, Iraq, liqaadr@gmail.com \\ 22Department of Petroleum Engineering, University of Baghdad, Baghdad, Iraq,sameerahmdulla@yahoo.com \\ *corresponding author: Sameera M.Hamd-Allah,sameerahmdulla@yahoo.com \\ Published online: 31 December 2020
}

Abstract - One of the most important enhanced oil recoveries methods is miscible displacement. During this method preferably access to the conditions of miscibility to improve the extraction process and the most important factor in these conditions is miscibility pressure. This study focused on establishing a suitable correlation to calculate the minimum miscibility pressure (MMP) required for injecting hydrocarbon gases into southern Iraq oil reservoir. MMPs were estimated for thirty oil samples from southern Iraqi oil fields by using modified Peng and Robinson equation of state. The obtained PVT reports properties were used for tunning the equation of state parameters by making a match between the equation of state results with experimental PVT data. The values of the MMPs inputs into the statistical program to find a correlation for the value of miscibility pressure with the properties and composition of the reservoir oil and injected gas. Using a nonlinear formula, a good correlation was obtained. When comparing the present correlation with the many measured data, a superbly result of present correlation was obtained.

Keywords-Correlation, Gas injection, Minimum miscibility pressure.

\section{Introduction}

Injection of a mixture of hydrocarbon gases is one of the most commonly applied (EOR) processes because there was a large amount of gas usually associated with crude oil, which can be separated and reinjected into the reservoir[2]. The gas injection can be a very efficient method for improving the production of oil, especially in the case when miscibility develops during the oil displacement process[14]. The essential objective of miscible gas injection is to get better local displacement efficiency and reduce (irreducible) residual oil saturation below much that typically obtained by the immiscible process. MMP is an important design parameter used during miscible gas injection. Where MMP is the lowest pressure for which the injection gas can develop miscibility with reservoir oil at reservoir temperature. There are different methods for the MMP estimation such as experimental measurement (for example the slim tube, vanishing interfacial tension, high-pressure visual sapphire cell, rising bubble apparatus), computational methods that depending on Equation of State and there were empirical correlations $[1,9,17]$.
The main approach for this work would be to make a semi-empirical correlation based on EOS for MMP estimation for hydrocarbon gas injection applicable in the southern Iraqi oil fields.

It was found that the independent variables for the predicated correlation are; reservoir temperature, mole fraction of intermediate component and molecular weight of $\mathrm{C}_{6+}$ in reservoir fluid, methane mole fraction and molecular weight of $\mathrm{C}_{2}-\mathrm{C}_{5}$ in the injected gases.

Kuo,(1985)[18] applied a new correlation for calculating MMP by enriched gas injection. This correlation can be used to determine MMP for fixed gas composition or predict $\mathrm{C}_{1}$ concenteration for a given pressure. The new correlation compared with the results of the slim tube apparatus and showed a good agreement with an average prediction error on MMP of less than $4 \%$.

Firoozabadi et al,(1986) [1] suggested a generalize correlation to predict MMP of reservoir fluids by use lean natural gas or $\mathrm{N}_{2}$ for injection. It was considered that the influencing factors are the concentration of the intermediate component, reservoir temperature and molecular weight of $\mathrm{C}_{7+}$, without considering gas composition effect. 
Zarenezhad,(2016)[5] developed a new correlation as a modification to the Firoozabadi and Aziz correlation. This correlation is a function of the most influencing variables such as $\mathrm{C}_{2}-\mathrm{C}_{6}$ composition and $\mathrm{C}_{7+}$ molecular weight in the reservoir oil, reservoir temperature, $\mathrm{C}_{2+}$ mole fraction and $\mathrm{C}_{2+}$ molecular weight in the injected gas. Comparison of the important existing correlations with the suggested correlation shows that this correlation is more accurate than the existing correlations with (AAD $=2.61 \%$ )and $\left(\mathrm{R}^{2}=0.9681\right)$. The experimentally measured data are in excellent agreement with the predicted results. Therefore the proposed new correlation was considered a reliable correlation for prediction accurate MMP value for EOR process.

\section{Area of Study.}

Thirty oil samples were collected from many formations that are located in southern Iraqi oil fields, for example, Abo Grab filed/Asmari formation/well 1 as illustrated below in Table 1 .

Table 1: Sources of PVT samples.

\begin{tabular}{|c|c|}
\hline Fields & Formation \\
\hline Abo Grab & Asmri \\
\hline Amara & Mishrif,Yamama B1 \\
\hline Buzurgan & Naher Umer, Khasaib \\
\hline Halfaya & B2,Yamama B3 \\
\hline Nasiriyah & Nuherumer,Mishirif,yamama \\
\hline $\begin{array}{c}\text { Naher } \\
\text { Umer }\end{array}$ & Mubair,Naher Umer,Yamama \\
\hline Majnoon & Suliay, Zubair \\
\hline Ratawi & Ratawi,Yamama,Naher Umer \\
\hline Rumaila & Mishrif \\
\hline West & Zurna \\
\hline Zubair & Zubair,Mishrif,Yamama,Ratawi \\
\hline Faqa & MIshrif MB21 \\
\hline Tuba & Mabair \\
\hline
\end{tabular}

\section{METHODOLOGY}

\subsection{PVT Simulator.}

In this study, a PVT model has been built by using PVTi (v.2014). A compositional PVT program base on the equation-of-state has been adopted to predict reservoir fluid properties for the reservoir samples. This simulator uses four equations of state for predicting different reservoir fluid properties. These are; Redlich-Kwong [3,8] Soave-Redlich-Kwong[19], Peng and Robinson [7] and Zudkevitch-Joffe[6] equations. also available two of three-parameter extensions of the Peng-Robinson EOS, one based on a Peneloux et al. [3] volume shift, the other being an implementation of the Schmidt-Wenzel Equation of State modified Peng-Robinson EOS[4], in addition to 2-parameter Peng-Robinson. And the SoaveRedlich-Kwong[21] Equation of State also has a threeparameter extension.

It is necessary to have a very actual physical model for a reservoir fluid samples before using them in miscibility calculation. Simulation of experiments that conducted in the laboratory on fluid samples should be done and then any observations that can be performed during a laboratory experiment can be made by theoretical predictions, in order to test the accuracy of our fluid model.

\subsection{Simulation of PVT Laboratory Data by the Equations of State.}

Before using the equation of state model in the experiment simulation study, the selected EOS should be able to achieve a good match between the results of EOS and the data of the PVT test. It should be noted that the EOS generally is not a good predictive without the regression process for tuning the parameters of EOS to match the experimental data. The phase behaviour models based on EOS may predict some erroneous results because the real reservoir fluids composed of thousands of components are described by a limited number of carbon groups and pure substances. The predicted compositional results of these fluids are not always very realistic and the carbon groups are not fully defined therefore the parameters of the selected equation of state must be adjusting to achieve a perfect matching between the observed laboratory PVT data and calculated by EOS. The regression method that used is Gani and Fredenslund(1987) [13]. The laboratory PVT data used in this study included differential liberation-expansion (DL) experiment. The main parameters that inserted into the PVTi software are components and their mole fractions, $\mathrm{C}_{7+}$ (sp.gr and molecular weight), DL experimental data, i.e., gas-oil ratio, compossibility factor, formation volume factor, relative volumes and gas gravity. Finally, after a well-characterized for fluid sample by EOS then we can simulate the multiple contact miscibility between crude oil and the injected gas at reservoir temperature in order to estimate the minimum 
miscibility pressure. The MMPs value for all sample calculated by EOS and represented in Table 2.

\section{Injection Gas Composition.}

The injected gas design greatly contributes to the success of the miscible gas displacement process. Gas injection is used to improve oil recovery and the gas used for injection is typically natural gas, $\mathrm{N}_{2}, \mathrm{CO}_{2}$ and flue gases but these gases do not recover oil as well as the hydrocarbon gases[15]. So in order to achieve miscibility between the injected gas and reservoir fluid at the lowest pressure, the composition of injected gas should be close to the composition of equilibrium gas with crude oil in the reservoir. For this reason, the produced gas is a good source for gas injection and it is more economical to reinject part or all of the produced gas into the reservoir[12]. Therefore the injected gases used in this study have a composition similar to that of the gas coming out of the separator.

\section{Correlation Prediction of the MMP.}

The estimated formula should have an acceptable correlation coefficient (R) and less value of average absolute percent relative error (AAERR) and standard deviation(SD). Many attempts were done on correlating independent variables with MMPs by selection a form of correlation estimation. Many trials were done by changing the variables. Finally, the best correlation is found for MMP as a function of (temperature (T), the molecular weight of heptane plus $\left(\mathrm{Mwc}_{7+}\right)$ and mole percent of intermediate component $\left(\mathrm{C}_{2}-\mathrm{C}_{6}+\mathrm{X}_{\mathrm{H} 2 \mathrm{~S}}+\mathrm{XcO}_{2}\right)$ in reservoir oil, $\mathrm{Xc}_{1}$ and molecular weight of $\left(\mathrm{C}_{2}-\mathrm{C}_{5}\right)$ in the injected gas. The following form is selected to represent the new correlation.

$\mathrm{MMP}=\mathrm{A}+\left(\mathrm{B} M w_{\mathrm{C} 7+}^{1.7}\right)+\left(\mathrm{J} X_{\mathrm{C} 2-\mathrm{C} 6+\mathrm{H} 2 \mathrm{~S}+\mathrm{CO} 2}^{-0.39851}\right)$ $\left(\mathrm{T}^{\mathrm{c}}\right)\left(\mathrm{L} M w_{C 2-C 5 \text { gas }}^{2.5}\right)+\left(\mathrm{M} \mathrm{Xc}_{1}+\mathrm{P} \mathrm{Xint} \mathrm{T}^{\mathrm{C}}\right)$

where

(A,B,C,J,M,P) a suitable coefficient and exponents for this formula. After substituting the value of this coefficient the correlation it becomes.

$$
\begin{aligned}
& \mathrm{MMP}=\quad 6.36779 \quad+\quad\left(0.0005 M w_{C 7+}^{1.7}\right) \\
& \left(0.0565 X_{\mathrm{C} 2-\mathrm{C} 6+\mathrm{H} 2 \mathrm{~S}+\mathrm{C}}^{-0.7385}\right)\left(\mathrm{T}^{0.10143}\right)\left(0.05616 \mathrm{Mw}_{C 2-C 5 g a s}^{2.5}\right) \\
& +\left(0.71143 \mathrm{Xc}_{1}-0.0010887 X_{\text {C1 gas }}^{1.6} \text { Xint } \mathrm{T}^{-0.10143}\right)
\end{aligned}
$$

The correlation coefficient $(\mathrm{R})$ of this correlation is 0.9

$\mathrm{Mw}_{\mathrm{C} 7+:}$ molecular weight of heptane plus, Lb mole.

$\mathrm{X}_{\mathrm{C} 2-\mathrm{C} 6+\mathrm{H} 2 \mathrm{~S}+\mathrm{CO} 2}$ : intermediate mole fraction in oil.

$\mathrm{X}_{\mathrm{C} 7+\text { : mole fraction of heptane plus in oil. }}$

$\mathrm{X}_{\mathrm{Clgas}}$ : mole fraction of methane in injection gas.

$\mathrm{Mw}_{\mathrm{C} 2-\mathrm{C} 5}$ : intermediate molecular weight in injection gas.
Table 2 represents the independent variable for the predicted correlations, MMP estimated by EOS, MMP calculated by the predicted correlations, the difference (residual) between the observed and calculated.

The convergence of estimated MMP by EOS and MMP calculated by the new correlation is shown below in figure 1 .

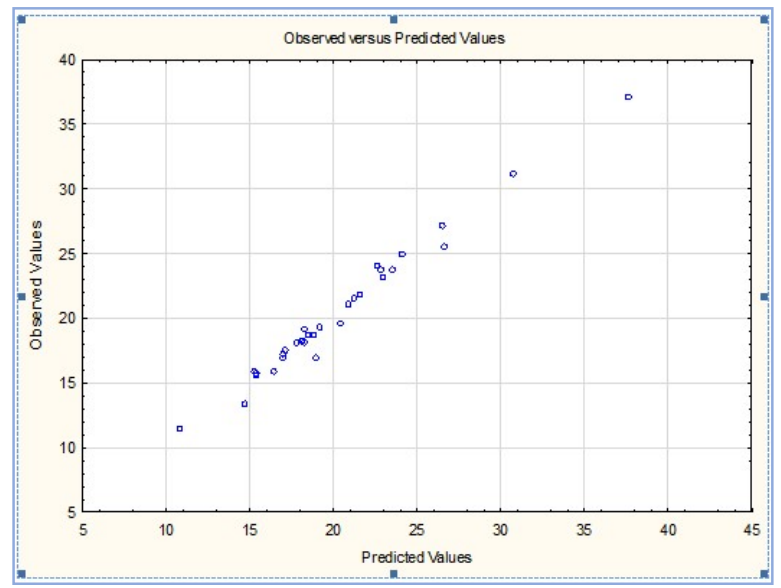

Figure 1: comparison of MMP estimated by EOS with MMP predicted by new correlation.

Figure2 illustrates the difference between MMP predicted by new correlation and MMP estimated by EOS. These point lie between $(-0.5$ to $0.5 \mathrm{Mpa})$ that indicate a good predicted values.

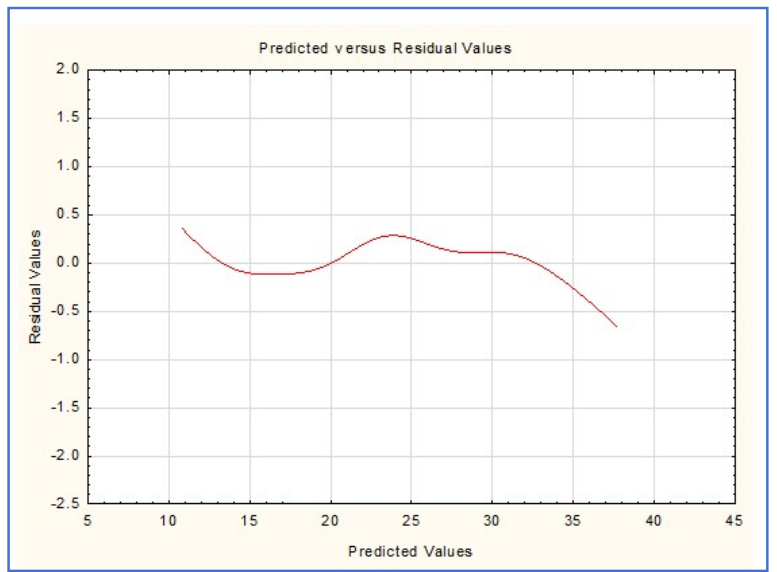

Figure 2: Residual versus predicted values 
Table 2:MMPs calculated by EOS and by new correlation

\begin{tabular}{|c|c|c|c|c|c|c|c|c|c|}
\hline Formation & $\begin{array}{c}\text { Saturation } \\
\text { pressure }\end{array}$ & $\begin{array}{l}\mathrm{MW} \\
\mathrm{C}_{7+}\end{array}$ & $\begin{array}{c}\mathrm{X}_{\mathrm{C} 2-\mathrm{C} 6} \\
+\mathrm{H} 2 \mathrm{~S} \\
+\mathrm{CO} 2\end{array}$ & $\begin{array}{c}\mathrm{X}_{\mathrm{INC1}} \\
\text { gas }\end{array}$ & $\begin{array}{l}\mathrm{MW}\left(\mathrm{C}_{2}\right. \\
\left.-\mathrm{C}_{5}\right) \mathrm{gas}\end{array}$ & $\mathrm{T}\left(\mathrm{F}^{\mathrm{o}}\right)$ & $\begin{array}{l}\text { Predicte } \\
\text { d by } \\
\text { EOS } \\
\text { (Mpa) }\end{array}$ & $\begin{array}{c}\text { predicted } \\
\text { correlation } \\
(\mathrm{Mpa})\end{array}$ & $\begin{array}{l}\text { Resid } \\
\text { ual } \\
\text { (Mpa) }\end{array}$ \\
\hline Abo Grab(Asmri) & 16.51 & 370 & 24.75 & 25.64 & 34.8 & 192 & 16.87 & 16.945 & -0.075 \\
\hline Amara 1(Mishrif) & 19.09 & 478 & 29.29 & 18 & 34.80 & 190 & 19.189 & 19.010 & 0.179 \\
\hline Amara 2 (Yamama B1) & 23.71 & 502 & 38.33 & 27.2 & 39.22 & 275 & 23.95 & 23.786 & 0.164 \\
\hline Amara 4 (Mishrif) & 18.31 & 330 & 32.37 & 35.15 & 35.06 & 210 & 19.07 & 18.746 & 0.324 \\
\hline Buzurgan 6_mc1 & 18.14 & 380 & 28.07 & 23.95 & 25 & 235 & 18.598 & 18.486 & 0.112 \\
\hline Buzurgan16(Mishirif) & 20.2 & 369 & 30.95 & 35.4 & 34.71 & 230 & 21.067 & 21.258 & -0.191 \\
\hline Buzurgan 12 (Mishirif) & 13.33 & 286 & 29.7 & 29.19 & 29.72 & 231 & 15.789 & 15.512 & 0.277 \\
\hline Faqa(Mishrif) & 15.43 & 370 & 61.04 & 35.26 & 29.66 & 233 & 16.95 & 17.204 & -0.254 \\
\hline Halfaya 1 (NaherUmr) & 13.0 & 440 & 24.61 & 15.46 & 41.83 & 235 & 13.37 & 13.234 & 0.136 \\
\hline $\begin{array}{c}\text { Halfaya } 045 \text { (Khasib } \\
\text { B2) }\end{array}$ & 19.23 & 360 & 20.557 & 35.91 & 41.83 & 198 & 19.567 & 19.940 & -0.373 \\
\hline $\begin{array}{c}\text { HF158- } \\
\text { N158(KHASIB) }\end{array}$ & 23.41 & 395 & 24.03 & 32.24 & 29.067 & 201 & 23.623 & 23.211 & 0.412 \\
\hline Majnoon 5 (Mishrif) & 17.67 & 340 & 26.36 & 27.26 & 26.120 & 379 & 18.056 & 18.326 & -0.270 \\
\hline NaherUmer 1 (Zubair) & 13.3 & 256 & 25.55 & 48.39 & 32.256 & 217 & 23.067 & 23.302 & -0.235 \\
\hline $\begin{array}{l}\text { NaherUmer4(NaherUm } \\
\text { r) }\end{array}$ & 9.41 & 180 & 24.09 & 26.6 & 26.683 & 196.0 & 11.356 & 11.121 & 0.235 \\
\hline NaherUmr 9 (Yamama) & 14.19 & 156 & 24.99 & 40.05 & 33.734 & 240 & 15.534 & 15.744 & -0.210 \\
\hline Nasirya 1 (Mishrif) & 26.8 & 435 & 27.69 & 35.89 & 27.66 & 165 & 27.165 & 26.906 & 0.259 \\
\hline Nasirya1(Yamama B3) & 30.79 & 540 & 20.11 & 29.04 & 31.4 & 217 & 31.134 & 30.524 & 0.610 \\
\hline Nasirya1(YamamaB2) & 15.37 & 240 & 31.22 & 35 & 31.428 & 214 & 15.674 & 15.684 & -0.010 \\
\hline Nasirya3(NuherUmer) & 14.35 & 292 & 32.74 & 34.92 & 29.142 & 186 & 18.045 & 17.932 & 0.113 \\
\hline Ratawei 6(Yamama) & 15.91 & 188 & 34.58 & 40.05 & 28.711 & 244 & 15.798 & 15.941 & -0.143 \\
\hline Ratawi 12(Ratawi) & 21.31 & 440 & 27.28 & 30.11 & 40.748 & 219 & 21.533 & 21.440 & 0.093 \\
\hline Ratawi 16 (NaherUmr) & 17.35 & 426 & 35.23 & 20 & 32.163 & 240 & 17.456 & 17.380 & 0.076 \\
\hline Rumaila (Sulay) & 23.59 & 410 & 28.85 & 32.53 & 29.561 & 251 & 23.7654 & 23.637 & 0.129 \\
\hline Tuba(Zubair) & 24.61 & 460 & 61.8 & 35.6 & 29.89 & 235 & 24.934 & 22.314 & 2.620 \\
\hline Rumaila (Zubair) & 18.41 & 370 & 25.41 & 27 & 29.193 & 210 & 18.643 & 18.976 & -0.333 \\
\hline West qurna (Mishirif) & 17.01 & 273 & 24.839 & 35 & 32.890 & 174 & 17.245 & 17.484 & -0.239 \\
\hline Zubair 36 (Mishirif) & 13.69 & 364 & 31.99 & 39.62 & 35.637 & 169 & 21.823 & 22.068 & -0.245 \\
\hline Zubair 202 (Yamama) & 35.11 & 560 & 20.63 & $\begin{array}{c}15.55 \\
3\end{array}$ & 25.569 & 239 & 25.523 & 25.347 & 0.176 \\
\hline Zubair 205 (Zubair) & 17.94 & 350 & 28.08 & 24.27 & 14.957 & 235 & 18.243 & 18.157 & 0.086 \\
\hline Zubair_(Ratawi) & 35.65 & 360 & 24.271 & 70.54 & 34.223 & 206 & 37.034 & 37.397 & -0.363 \\
\hline
\end{tabular}




\section{Comparison between the predicted correlation's value with the experimental value.}

In order to validate the predicted correlation in calculating the MMP value, we must compare the results of this correlation with the experimental values. This correlation was tested on published laboratory data in many literatures as (M. Kanatbayev,2016), ( C. A. Hutchinson 1958), (S. S. Kuo,2007), (Williams, 1980). We note that the MMP values increase with increasing (temperature, $\mathrm{C}_{7+}$ molecular weight in the reservoir fluid, $\mathrm{C}_{1}$ in the injection gas). In general, miscibility pressure increases with increasing temperature because the solubility of hydrocarbons decreases with increasing temperature, which causes the size of the two-phase region to increase. MMP increase with increasing $\mathrm{C} 7+$ molecular weight because the increasing in $\mathrm{C} 7+$ molecular weight means that the oil has become heavier, so it needs a higher pressure to get miscible. The increase in methane percentage makes the gas composition significantly different from the composition of the oil. The MMP decreases with increasing (mole percent of $\mathrm{C}_{2}$ -
$\mathrm{C}_{6}-\mathrm{H}_{2} \mathrm{~S}$ in the reservoir fluid, molecular weight of $\mathrm{C}_{2}-\mathrm{C}_{5}$ in the injection gas) this is because the increase in the intermediate compounds in the gas makes its composition similar to the oil composition and the increase in the intermediate compounds in the oil makes it lighter.

Firstly AERR (absolute relative error) was calculated for each value then the AAERR (average absolute relative error) for all values was calculated. The AERR and AAERR equations were listed below eq 3 and eq 4 . As shown in Table 3 the results were very close to the experimental result with AAERR $=9.4 \%$. This means that the proposed correlation has an acceptable accuracy in calculation MMP value.

$-A E R R=((X \exp -X e s t) / X \exp ) * 100 \%$

- $A A E R R=\left(\frac{1}{n_{d}}\right) \sum_{i=1}^{n_{d}}|A E R R|$

Where

Xest : estimated value

Xexp : experimental values.

Table3: Comparison between predicted correlation with the experimental value.

\begin{tabular}{|c|c|c|c|c|c|c|c|c|}
\hline $\begin{array}{l}\text { Refr- } \\
\text { ences }\end{array}$ & $\mathrm{MWC}_{7+}$ & $\begin{array}{c}\mathrm{X} \\
\mathrm{C2}-\mathrm{C} 6+\mathrm{H} 2 \mathrm{~S} \\
+\mathrm{CO} 2\end{array}$ & $\mathrm{X}_{\mathrm{INC} 1}$ & $\begin{array}{c}\mathrm{MW}\left(\mathrm{C}_{2-}\right. \\
\left.\mathrm{C}_{5}\right)\end{array}$ & $T(f)$ & $\begin{array}{l}\text { MMP } \\
\text { (EXP) }\end{array}$ & $\begin{array}{c}\text { Predicted } \\
\text { Correlation } \\
(\mathrm{Mpa})\end{array}$ & AERR $\%$ \\
\hline [18] & 300 & 1.43 & 65 & 44 & 132 & 23.30 & 25.717 & 10.352 \\
\hline [18] & 300 & 1.43 & 62.4 & 44 & 132 & 25.17 & 23.915 & 4.972 \\
\hline [18] & 300 & 1.43 & 54.3 & 44 & 132 & 18.96 & 18.293 & 3.520 \\
\hline [18] & 191 & 23.57 & 52.88 & 39.9 & 170 & 16.55 & 20.931 & 26.492 \\
\hline [18] & 191 & 23.57 & 52.88 & 39.9 & 206 & 18.48 & 21.203 & 14.748 \\
\hline [20] & 183 & 32.17 & 68.5 & 35 & 130 & 23.44 & 23.861 & 1.787 \\
\hline [10] & 217 & 25.84 & 65 & 30 & 140 & 24.13 & 28.414 & 17.744 \\
\hline [16] & 258 & 31.92 & 65.9 & 12.2 & 249.8 & 27.40 & 30.427 & 11.049 \\
\hline [16] & 275 & 23.6 & 80.78 & 6.12 & 282 & 46.60 & 41.738 & 10.433 \\
\hline [16] & 274 & 31.25 & 76.22 & 9.22 & 196 & 32.60 & 34.262 & 5.098 \\
\hline [16] & 296 & 28.61 & 66.09 & 11.96 & 249.8 & 30.00 & 33.826 & 12.754 \\
\hline [16] & 255 & 24.03 & 77.41 & 6.77 & 285.8 & 37.20 & 39.302 & 5.651 \\
\hline [16] & 280 & 23.69 & 82.03 & 5.77 & 195.8 & 39.72 & 41.747 & 5.104 \\
\hline [16] & 283 & 27.1 & 82.03 & 5.77 & 194 & 37.25 & 39.354 & 5.648 \\
\hline [16] & 280 & 26.13 & 82.03 & 5.77 & 194 & 37.72 & 39.936 & 5.874 \\
\hline$[16]$ & 273 & 31.91 & 76.17 & 8.71 & 193.82 & 31.00 & 33.767 & 8.926 \\
\hline
\end{tabular}




\begin{tabular}{|c|c|c|c|c|c|c|c|c|}
\hline$[16]$ & 260 & 27.63 & 64.5 & 11.27 & 225.5 & 29.50 & 32.044 & 8.624 \\
\hline$[16]$ & 197.6 & 36.06 & 70.49 & 10.57 & 222 & 29.80 & 27.064 & 9.180 \\
\hline$[16]$ & 266 & 28.89 & 70.64 & 10.3 & 194 & 28.4 & 33.597 & 18.299 \\
\hline$[16]$ & 316 & 23.79 & 62.39 & 13.82 & 180.5 & 31.8 & 35.131 & 10.476 \\
\hline$[16]$ & 320 & 23.53 & 62.63 & 13.8 & 180.5 & 31.4 & 35.549 & 13.213 \\
\hline$[16]$ & 250 & 27.7 & 70.97 & 10.95 & 208.4 & 33.4 & 33.826 & 1.276 \\
\hline$[16]$ & 250 & 27.7 & 76.17 & 8.71 & 208.4 & 34.2 & 35.686 & 4.346 \\
\hline & & & & & & & AAERR $=$ & 9.4 \\
\hline
\end{tabular}

\section{Conclusions}

1- A new correlation for accurate prediction of the MMP in southern Iraqi oil filed have been proposed regarding hydrocarbon gas injection.

2-The proposed correlation is a function of the most influencing variables that are (reservoir temperature, $\mathrm{C}_{2-6}+\mathrm{H}_{2} \mathrm{~S}+\mathrm{CO}_{2}$ composition in the oil, the molecular

\section{References.}

[1] A. Firoozabadi and K. Aziz, "Analysis and Correlation of Nitrogen and Lean-Gas Miscibility Pressure.," SPE Reserv. Eng. (Society Pet. Eng., vol. 1, no. 6, pp. 575-582, 1986.

[2] A. Nabilou, "EOR Methods Best Method for Enhanced Oil Recovery from Sarvak Reservoir and Analyse Sensitive Parameters," Tecnico, no. September, 2016.

[3] A. Harmens and D. E. Jeremiah, "On twoparameter equations of state and the limitations of a hard sphere Peng-Robinson equation," Cryogenics (Guildf)., vol. 25, no. 2, pp. 60-62, 1985.

[4] B. S. Jhaveri and G. K. Youngren, "Threeparameter modification of the Peng-Robinson equation of state to improve volumetric predictions," SPE Reserv. Eng. (Society Pet. Eng., vol. 3, no. 3, pp. 1033-1040, 1988.

[5] D. Zhou and F. M. Orr, "An Analysis of Rising Bubble Experiments to Determine Minimum Miscibility Pressures," SPE J., vol. 3, no. 01, pp. 19-25, 2007.

[6] D. Zudkevitch and J. Joffe, "Correlation and Prediction of Vapor-Liquid Equilibria with the Redlich-Kwong Equation of State," no. 7, pp. 112-119, 1970.

[7] D. Peng and D. B. Robinson, "A New Two- weight of $\mathrm{C}_{6+}$ in the oil, $\mathrm{C}_{1}$ composition in the gas,

and injected gas $\mathrm{C}_{2-5}$ molecular weight.

3- The predicted results are in good agreement with

MMPs estimated by EOS and experimentally measured

data suggesting that the new proposed correlation is

reliable for MMP prediction.

Constant Equation of State," vol. 15, no. 1, pp. 59-64, 1976. [2]

[8] S. C. Ayirala, D. N. Rao, and J. Casteel, "Comparison of Minimum Miscibility Pressures Determined from Gas-Oil Interfacial Tension Measurements with Equation of State Calculations," 2007.

[9] F. P. Equilibria, L. D. C. Physique, D. S. Jtgme, and L. D. G. Chimique, “( $\mathrm{aV} / \mathrm{ani}) \mathrm{T},, \mathrm{n},(\mathrm{j}+$ i ;”, vol. 8, no. I 982, pp. 7-23, 1982.

[10]H. A. K. Jr and C. A. H. Jr, "Miscible Displacements of Reservoir Oil U sing Flue Gas."

[11]I. C., N. N., O. O., and N. S., "Evaluation of Parameters That Affect Minimum Miscibility Pressure During Gas Injection Processes.," Int. J. Adv. Res., vol. 5, no. 2, pp. 165-173, 2017.

[12]I. Farzad and M. Amani, "Evaluating Reservoir Production Strategies in Miscible and Immiscible Gas-Injection Projects," 2007.

[13] Gani, R., and Fredenslund, A., "Thermodynamics of Pe troleum Mixtures Containing Heavy Hydrocarbons Am Expert Tuning System", Industrial and Engineering Chemistry Research.

[14] G. F. Teletzke, P. D. Patel, and A. L. Chen, 
"Methodology for miscible gas injection EOR screening," IIORC 05 - 2005 SPE Int. Improv. Oil Recover. Conf. Asia Pacific, Proc., pp. 315325, 2005.

[15] G. Platforms, O. Recovery, W. Injection, and H. Pressure, "Systems and Equipment for Offshore Platform Design," 2016.

[16]M. Kanatbayev, K. K. Meisingset, K. Uleberg, and S. Asa, "Comparison of MMP Estimation Methods with Proposed Workflow," no. April, pp. 1-11, 2015

[17] Production co., Amoco, “An Iterative Sequence for Phase-Equilibria Calculations Incorporating the Redlich-Kwong Equation of State.” 1977
[18] S. S. Kuo, "Prediction of Miscibility for the Enriched-Gas Drive Process," no. 1, 2007.

[19] T. H. E. Redlich-kwong, “(2) (3),” vol. 27, no. 6, pp. 1197-1203, 1972.

[20] Williams1980, “USE OF THE PENGROBINSON EQUATION OF STATE TO PREDICT HYDROCARBON PHASE BEHHAVIOR AND MISCIBILITYF FOR FLUID DISPLACEMENT."

[21] Y. Wei, Z. Chen, M. Satyro, C. Dong, and H. Deng, "Compositional simulation using the advanced Peng-Robinson equation of state," Soc. Pet. Eng. - SPE Reserv. Simul. Symp. 2011, vol. 2, no. 1976, pp. 983-994, 2011.

\section{معادلة لحساب اقل ضغط للامتزاج عند حقن الغازات الهيدروكاريونية في حقول جنوب العراق \\ لقاء إبراهيم هادي1، سعبرة محد حمد الله2،} liqaadr@gmail.com،قسم هنسة النفط جامعة، بغداد،بغداد، العر/ق sameerahmdulla@yahoo.com، قسم هنسسة النفط، جامعة بغداد، بغداد، العراق، sameerahmdulla@yahoo.com الباحث المثل: سمبيرة محد حمداله، البريي الاكتتروني:

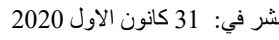

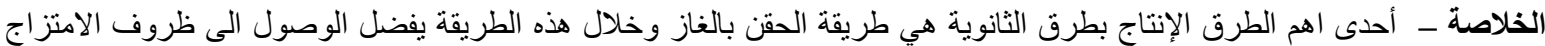

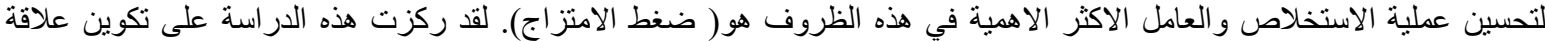

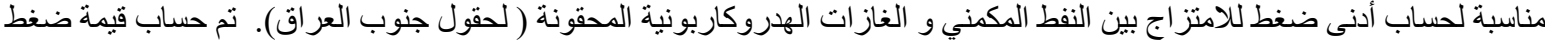

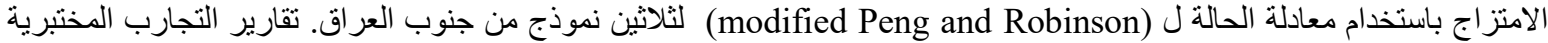

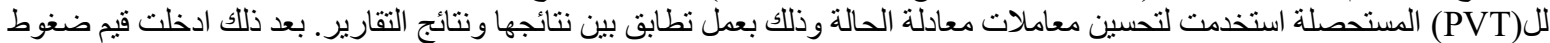

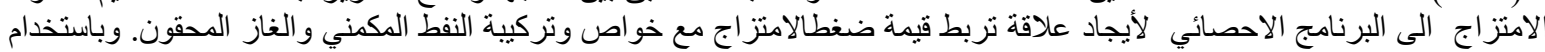

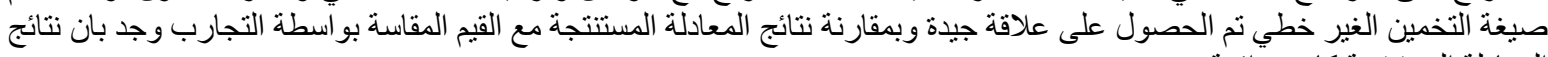
المعادلة المستنتجة كانت رائعة.

$$
\text { الكلمات الرئيسية -ضغط الامتز اج، معادلة لحساب ضغط الامتز اج، حقن الغازات الهيدروكاربونية. }
$$

